\title{
Effect of simplifying winter feeding in suckling herds
}

\author{
N Grenet 1, J Billant 2 \\ IInstitut de l'Elevage, Theix, 63122 St-Genès-Champanelle; 2LEGTA, 52903 Chaurnont Cedex 9, France
}

Depending on farm resources, two forages of unequal value are often distributed daily to beef herds. To gain time for animal care, they could be given alternately at several days interval but the subsequent ration imbalance and varying levels of energy might affect animal performances.

Six trials were performed with Limousine animals, three with 1 -year-old heifers $(\mathrm{H} 1)$, two with 2-year-old heifers $(\mathrm{H} 2)$ and one with multiparous suckling cows (SC). For each trial, which lasted at least 110 days, two groups (control and experimental) of 10 to 12 heifers were formed on the basis of age, weight and previous growth while the cows were allotted to groups of 18 according to weight and calving date. $\mathrm{H} 1$ received a diet of limited amounts of grass silage and hay for two years, grass silage and maize silage the third year, $\mathrm{H} 2$ and SC a diet of grass silage and straw. Rations were balanced by cereals and soya meal for growth of about 600 or $300 \mathrm{~g} /$ day in $\mathrm{H} 1$ and $\mathrm{H} 2$ respectively and weight loss of $20-25 \mathrm{~kg}$ for the cows (INRA recommendations 1988, "L'alimentation des bovins, ovins et caprins" edited by R Jarrige, INRA Publ, Paris). In each case, the control group $(C)$ received all ration constituents daily while the experimental group (E) received grass silage from Monday to Friday and hay, straw and concentrate or maize silage the weekend in such a way that all animals received exactly the same amounts in a week (dry matter and calculated energy)

The animals were weighed on two consecutive days at the same hour after pre-and postexperimental periods of ten days during which grass silage alone was given $(\mathrm{H} 1,5 \mathrm{~kg}$ of dry matter, $\mathrm{H} 2,7 \mathrm{~kg}$ and $\mathrm{SC}, 10 \mathrm{~kg}$ ) to eliminate fluctuations in digestive content. Subsequent growth at pasture was also measured.

There was no effect of year and so results were grouped together. Alternate forage distribution significantly affected growth in $\mathrm{H} 1$ (-88 $\mathrm{g} /$ day) and $\mathrm{H} 2(-77 \mathrm{~g} /$ day, a difference close to the $5 \%$ threshold). Compensatory growth at pasture was not sufficient to totally offset winter delay ; for a standard indoor wintering of 180 days $(\mathrm{H} 1)$ or 150 days $(\mathrm{H} 2)$ and 210 days at pasture, the final weight difference would be 11 and $9 \mathrm{~kg}$. The cows also lost more weight (NS) but completely made up the difference at pasture.

In conclusion, simplifying feeding did not affect animal health but reduced feed efficiency and consequently growth of heifers. Young animals are more sensitive to abrupt feed variations. To maintain growth would require an extra daily cost of 0.25 feed unit, ie $80 \mathrm{~kg}$ of concentrates over two winters with the same efficiency.A study of reproduction in a larger number of cows is also needed.

\begin{tabular}{lcccccccc}
\hline Animal type & \multicolumn{2}{c}{ H1 } & & \multicolumn{2}{c}{ H2 } & \multicolumn{3}{c}{$\mathrm{SC}^{1}$} \\
Group & $\mathrm{C}$ & $\mathrm{E}$ & $\mathrm{C}$ & $\mathrm{E}$ & $\mathrm{C}$ & $\mathrm{E}$ \\
\hline Experimental ADG $(\mathrm{g})$ & $597^{* *}$ & 509 & 363 & 286 & -25.5 & -34.4 \\
Pasture ADG (g) & 618 & 641 & & 513 & 527 & 62.0 & 72.5 \\
Final weight difference (C - E in kg) & \multicolumn{2}{c}{-11} & & & -9 & & \multicolumn{2}{c}{+1.8} \\
\hline
\end{tabular}

1 Weight variation in $\mathrm{kg}$

** Significant difference at threshold of $1 \%$ 